\title{
Ograniczanie skuteczności prawa retraktu w polskim prawie ziemskim od II polowy XIV do końca XV wieku
}

\section{Beschränkung der Auswirkung des Rückkaufrechts im polnischen Landrecht von Mitte des 14. bis Ende des 15. Jhs.}

1. Uwagi wstępne: 1.1. przegląd literatury; 1.2. geneza prawa bliższości; 1.3. ostatni głos w literaturze w sprawie znaczenia prawa retraktu. 2. Rola i znaczenie prawa retraktu: próba całościowego spojrzenia. 3. Rodzaje ograniczeń prawa retraktu: 3.1. terminy przedawnień zgłaszania roszczeń; 3.2. terminy realizacji zasądzonych roszczeń retraktowych; 3.3. procedura; 3.4. tytuły prawne i podmioty; 3.5. zanik prawa retraktu. 4. Zgodność praktyki prawnej $\mathrm{z}$ normami statutowymi. 5. Podsumowanie.

1. Einleitende Bemerkungen: 1.1. Blick in die Literatur; 1.2. Entstehung des Folgerechts; 1.3. Derzeitiger Forschungsstand über die Bedeutung des Rückkaufrechts. 2. Bedeutung des Rückkaufrechts: Versuch einer Zusammenfassung. 3. Beschränkungen im Rückkaufrecht: 3.1. Termine der Verjährung der Anmeldungen der Forderung; 3.2. Termine der Realisierung der Rückkaufanspruchs; 3.3. Prozessverfahren; 3.4. Gesetzestitel und Rechtssubjekte; 3.5. Rückgang des Rückkaufansprüche. 4. Übereinstimmung der Rechtspraxis mit den Normen der Statuten. 5. Schlussfolgerungen.

1.1. W literaturze przedmiotu wielokrotnie próbowano definiować istotę prawa bliższości. Ostatnio klarowną definicję tej instytucji podal W. Uruszczak: Prawo bliższości polegalo na uprawnieniu każdego czlonka rodu zbywcy nieruchomości do jej odzyskania $w$ razie, gdyby akt zbycia odbywal sie bez jego zgody $i$ wiedzy ${ }^{1}$. Przejawami ius propinquitatis były: prawo pierwokupu, zgoda krewnych na alienacje i prawo retraktu². Tutaj przedmiotem analizy jest ostatnia ze wspomnianych instytucji.

* Składam serdeczne podziękowanie Profesorom Krzysztofowi Ożogowi i Wacławowi Uruszczakowi za cenne wskazówki i uwagi pomocne w pisaniu niniejszego tekstu.

${ }^{1}$ W. Uruszczak, Wladza ksiażęca, wiece sqqdowe $i$ prawo wlasności na Ślasku $w$ XIII $w$. $w$ świetle Ksiegi henrykowskiej, Czasopismo Prawno-Historyczne 2002, t. LIV, z. 1, s. 84.

$2 \mathrm{~J}$. B a r d a c h, Uwagi o rodowym ustroju spoleczeństwa i prawie bliższości w Polsce średniowiecznej, Czasopismo Prawno-Historyczne 1952, t. IV, s. 438. Pierwokup w żródłach pojawia się 
W historiografii polskiej prawem bliższości bardziej zainteresowano się $\mathrm{w}$ drugiej polowie XIX w. $^{3}$ Pierwszym obszernym artykułem poświęconym tej instytucji był tekst z 1877 r. P. Burzyńskiego ${ }^{4}$; autor przedstawil w nim pogląd, wedle którego nastąpiła recepcja prawa bliższości $\mathrm{z}$ obrębu praw obcych. R. Hube kilkakrotnie analizował cechy prawa bliższości ${ }^{5}$. K. Dunin w Dawnym mazowieckim prawie $(1880)^{6}$ zawarł oddzielny rozdzial poświęcony omawianej instytucji, w którym zarysowal podstawowe zagadnienia (zakres podmiotowy, przedmiotowy, tytuły podlegające zaczepieniu, geneza, regulacje dotyczące korzystania z instytucji). Kilka lat później (1906-1907) pojawiły się dwa artykuły N. Michalewicza ; autor przedstawił w nich glówne cechy instytucji na podstawie materiału źródłowego z terenu Wielkopolski. Nieodzownym jest także wspomnieć o dwutomowym dziele P. Dąbkowskiego - Prawo prywatne polskie ${ }^{8}$, w którym także wiele miejsca zostało poświęcone prawu bliższości. W okresie międzywojennym ius propinquitatis wielokrotnie wracało w historiografii przy okazji badań nad sytuacją gospodarczą ziem polskich w średniowieczu; wymienić tu trzeba choćby prace K. Tymienieckiego?

rzadko. Instytucja ta polegała na pierwszeństwie kupna alienowanej nieruchomości przez posiadającego lepsze ku temu prawo. Najprawdopodobniej musiały istnieć terminy zawite, po których krewniacy tracili prawo pierwokupu (Z. R y m a s ze ws ki, Prawo bliższości krewnych w polskim prawie ziemskim do końca XV wieku, Warszawa 1970, s. 128). Instytucja ta (poza Mazowszem, gdzie wystẹpuje jeszcze w XV w., por. ibidem, s. 15) zanikła w XIV w.; była mniej poręczną od prawa retraktu, ponieważ wymagała od krewniaka zdobycia w krótkim czasie gotówki. Zdaniem wspomnianego autora (ibidem, s. 112-113), powolującego się na ustalenia K. K ol á c z y k a, zgoda krewnych na alienację była reliktem wspólnego władania ziemią, nie występowała ona w księgach sądowych. Jej zanik, podobnie jak prawa pierwokupu, jest datowany na koniec XIV w. Inaczej twierdzi J. Wroniszewski, Szlachta ziemi sandomierskiej w średniowieczu. Zagadnienia spoleczne i gospodarcze, Wrocław 2001, s. 42.

${ }^{3}$ Pełen spis literatury przedmiotu do $1970 \mathrm{r}$. podaje Z. R y mas zewski, Prawo bliższości..., s. 193-196. Tutaj tylko kilka informacji bibliograficznych ilustrujących szerokie zainteresowanie prawem bliższości w historiografii polskiej.

${ }^{4}$ P. Burzyński, O prawie przyzwalania krewnych $w$ dawnej Polsce, Rozprawy Akademii Umiejętności, Wydz. Hist.-Filoz. 1877, t. VI, s. 21-52.

${ }^{5}$ R. H u be, Prawo polskie $w$ wieku XIII, Warszawa 1874, s. 108-111; t e nże, Prawo polskie w 14 wieku. Ustawodawstwo Kazimierza Wielkiego, Warszawa 1881, s. 128-129, 198; t en że, Sqdy ich praktyki i stosunki prawne spoleczeństwa w Polsce ku schylkowi 14 wieku, Warszawa 1886, s. 161-163, 231.

${ }^{6} \mathrm{~K}$. D u n in, Dawne mazowieckie prawo, Warszawa 1880, s. 156-160.

${ }^{7} \mathrm{~N}$. Michalewicz, O prawie przyzwalania krewnych na pozbywanie nieruchomości $w$ Wielkopolsce aż do ustawodawstwa Kazimierza Wielkiego, Przegląd Historyczny 1906, t. III, z. 2, s. 116-126; 1907, t. IV, z. 1, s. 98-112.

${ }^{8}$ P. Dąbkowski, Prawo prywatne polskie, t. I, Lwów 1910, s. 251, 455; t. II, Lwów 1911, s. 496-513.

${ }^{9} \mathrm{~K}$. T y mi en iecki, $Z$ dziejów rozwoju wielkiej wlasności na Ślasku w wieku XIII, Poznań 1927 , s. 16, 19, 23-25, 62; t en że, $Z$ dziejów zaniku drobnej wlasności na Ślasku w wieku XIII, [w:] Ksiega pamiq̨tkowa ku czci Oswalda Balzera, t. II, Lwów 1925, s. 624. 
Tematyka ta jest także widoczna w Najdawniejszym polskim prawie spadkowym K. Kolańczyka ${ }^{10}$. Cenne uwagi dotyczące prawa bliższości zamieścil w swych pracach $\mathrm{Z}$. Wojciechowski ${ }^{11}$. Intensyfikacja badań nad tą instytucją nastąpiła po II wojnie światowej. Prace J. Adamusa ${ }^{12}$, J. Bardacha ${ }^{13}$, K. Kolańczyka ${ }^{14}$, B. Lesińskiego ${ }^{15}$, J. Matuszewskiego ${ }^{16}$, S. Russockiego ${ }^{17}$, a także W. Sobocińskiego $^{18}$ mają najistotniejsze dla nas znaczenie. Wreszcie w 1970 r. ukazała się monografia $Z$. Rymaszewskiego ${ }^{19}$, zamykająca okres intensywnych dyskusji nad prawem bliższości.

Po 1970 r. ukazało się kilka artykułów poruszających problematykę ius propinquitatis $\mathrm{w}$ polskim prawie ziemskim. O ile w okresie wcześniejszym instytucja ta budziła zainteresowanie w kontekście badań nad gospodarką, nowsze prace dotyczą zagadnień spolecznych, szczególnie genealogicznych. W 1973 r. J. Bieniak przedstawil nowe spostrzeżenia na temat hierarchii korzystania z prawa bliższości ${ }^{20}$. W 2002 r. ukazał się artykuł W. Uruszczaka, w którym przedstawione zostało stosowanie prawa bliższości w XIII w. ${ }^{21}$ Wymienić trzeba tu także pracę J. Wroniszewskiego, Szlachta ziemi sandomierskiej $w$ średniowieczu ${ }^{22}$, również poruszającą problem retraktu $\mathrm{w}$ kontekście genealogii.

Niewątpliwie dobra praca Z. Rymaszewskiego nie przesądzila o zamknięciu wszystkich problemów związanych $\mathrm{z}$ ius propinquitatis. Należą do nich badania

${ }^{10}$ K. Ko la ń c zy k, Najdawniejsze polskie prawo spadkowe, Poznań 1939, s. 157, 270, przyp. 1.

${ }^{11} \mathrm{Z}$. Wojciechowski, Prawo rycerskie $w$ Polsce przed statutami Kazimierza Wielkiego, Poznań 1928, przyp. 34i, s. 62-65; te nże, Sqdownictwo prawa polskiego w dobie przedimmunitetowej, [w:] Studia z historii państwa $i$ prawa, t. XIII, z. 1, Lwów 1930, s. 34 i n., s. $43-45$, przyp. 3 .

${ }^{12}$ Np. J. Ad a m u s, Polska teoria rodowa, Lódż 1958.

${ }^{13}$ Por. przyp. 2.

${ }^{14}$ Por. K. Kol a ńczy k, Studia nad reliktami wspólnej wlasności ziemi w najdawniejszej Polsce. Rozporzqdzanie wlasnościq ziemskq do końca XV w., Poznań 1950, s. 274-283.

${ }^{15}$ B. Lesiński, Ze studiów nad prawem bliższości w XIV $i X V$ wieku, Czasopismo Prawno-Historyczne 1955, t. VII, z. 1, s. 92-108.

16 J. Matuszewski, Aqua abrenuntiationis, Czasopismo Prawno-Historyczne 1952, t. IV, s. $183-207$.

${ }^{17} \mathrm{~S}$. R u s s o ck i, Formy wladania ziemiq w prawie ziemskim Mazowsza (koniec XIV - polowa XVI wieku), Warszawa 1961, s. 96-108, 286-288.

${ }^{18}$ W. S o bociński [recenzja pracy K. Kolańczyka], „Roczniki Dziejów Społecznych i Gospodarczych" 1951, t. XIII, s. 335-337.

19 Por. przyp. 2.

${ }^{20} \mathrm{~J}$. B i eniak, Rody rycerskie jako czynnik struktury spolecznej w Polsce XIII-XV wieku. Uwagi problemowe, [w:] Polska w okresie rozdrobnienia feudalnego. Państwo - spoleczeństwo - kultura, red. H. Lowmiański, Wrocław 1973, s. 195-197.

${ }^{21}$ W. Uru zzczak, Wladza ksiqżęca..., s. 83-103.

22 J. Wroniszew ski, Szlachta ziemi..., s. 30, 39-42. 
dotyczące zasięgu podmiotowego oddziaływania instytucji ${ }^{23}$, jej pochodzenia, problemu zbieżności prawa stosowanego $\mathrm{w}$ praktyce $\mathrm{z}$ prawem skodyfikowanym, wreszcie zagadnienia skuteczności, znaczenia i częstotliwości występowania. W tym miejscu zostanie przedstawionych kilka uwag na temat ewolucji znaczenia tej instytucji $w$ średniowiecznym obrocie prawnym.

1.2. Rola prawa retraktu nieodłącznie związana jest $\mathrm{z}$ zagadnieniem jego genezy; tutaj na ten temat tylko kilka słów tytułem wstępu. W ubiegłym stuleciu starło się co najmniej sześć koncepcji pochodzenia tej instytucji, $\mathrm{w}$ tym miejscu wystarczy zwrócić uwage na kilka $\mathrm{z}$ nich ${ }^{24}$. W okresie międzywojennym odrzucono tezę promowaną już przez J. Lelewela, wedle której prawo retraktu było ekspektatywą krewnych na władaną przez członka rodu nieruchomośćc ${ }^{25}$. Dwie kolejne koncepcje wychodziły z założenia, wedle którego instytucja ta rozwinęła się na ziemiach polskich w XIII stuleciu. Przyczynę tego stanu badacze interpretują na dwa sposoby. K. Kolańczyk uważa, że w XIII w. nastąpiło przebudzenie uśpionej instytucji, immanentnie związanej z kontynuacją rodowego ustroju społeczeństwa od czasów pierwotnych. Wedkug J. Bardacha i Z. Rymaszewskiego, prawo retraktu powstało na gruncie własności indywidualnej ${ }^{26}$. Badacze ci przeczą ciągłości ius propinquitatis ze starożytnym retraktem gminnym, którego występowanie wśród Słowian stwierdzono choćby na podstawie bizantyjskich regulacji prawnych $\mathrm{z}$ VIII $\mathrm{w}^{27} \mathrm{~W}$. Uruszczak powrócił do koncepcji, wedle której u podstaw rozwoju prawa bliższości było wykształcenie się własności prywatnej poprzez nadania monarsze ${ }^{28}$.

Istotną sprawą jest odpowiedź na pytanie, dlaczego prawo retraktu $\mathrm{z}$ taką żywotnością pojawia się dopiero w połowie XIII stulecia. Czy jest to związane jedynie $\mathrm{z}$ brakiem źródel $\mathrm{z}$ lat wcześniejszych? ${ }^{29}$ Odpowiedź na pytanie o genezę wskazuje okoliczności, w ramach których wykształciła się omawiana instytucja. $\mathrm{Z}$ upływem lat zmiana tych warunków doprowadziła także do powstania innych potrzeb $w$ zakresie regulacji prawnej, co zaowocowało m.in. ograniczaniem skuteczności prawa retraktu.

${ }^{23}$ Problematyka zasięgu podmiotowego jest ściśle związana $z$ zagadnieniem istnienia rodów genealogicznych. Por. Z. R y mas zew ski, Prawo bliższości..., s. 29 i n.; J. B ie niak Rody rycerskie..., s. 178.

${ }^{24}$ Obszernie przedstawia ten problem Z. R y maszewski, Prawo bliższości..., s. 164-184.

${ }^{25}$ Zgodnie $z$ tą teorią należałoby zakwalifikować prawo bliższości do instytucji prawa spadkowego.

${ }^{26}$ J. B ardach, Uwagi..., s. 440.

${ }^{27}$ Ibidem, s. 441.

${ }^{28}$ W. Uruszczak, Wladza ksiqżęca..., s. 93.

${ }^{29}$ Zestawienia wzmianek o prawie bliższości w XII w. dokonali Z. Wojciechowski, Sqdownictwo..., s. 43-45, przyp. 3, oraz M. Sc z a n i c ki, Nadania ziemi na rzecz rycerzy w Polsce do końca XIII wieku, Poznań 1938, s. 48. 
Według tezy K. Kolańczyka, popieranej częściowo także przez Z. Rymaszewskiego, w XIII w. miał powstać wspólny, „rycersko-książęcy front" przeciwko wzrastającej sile gospodarczej Kościola ${ }^{30}$. Zgodnie z tym założeniem, retrakt rozwijał się w XIII w. w celu odzyskiwania dóbr alienowanych na rzecz instytucji kościelnych, najczęściej pod tytułem darmnym. O ile teza o wspólnym froncie jest bardzo kontrowersyjna, to koncepcje rozwoju retraktu $\mathrm{w}$ prawie ziemskim jako środka rewindykacji ziem rodowych należy uznać za całkowicie słuszną. Tym bardziej że zapoczątkowane $w$ pierwszej połowie XIII w. przekształcenia pod wplywem meliorationis terrae, stopniowo podnosily wartość zagospodarowanej ziemi, z czym wiązała się niechęć do nieodpłatnej alienacji wartościowych gruntów.

1.3. Początkowo (od momentu jego wykształcenia po pierwsze dekady XIV w.) prawo retraktu posiadało więc istotne znaczenie, a jego zapotrzebowanie w spoleczeństwie bylo stosunkowo wysokie ${ }^{31}$. Natomiast w świetle dotychczasowych badań, $w$ przeważającym stopniu dominuje przekonanie o niewielkim znaczeniu prawa retraktu $w$ obrocie prawnym $w$ XIV i XV stuleciach ${ }^{32}$. B. Lesiński na poparcie swej tezy przedstawia dane pochodzace z Kujaw; w latach 1418-1424 na 90 alienacji zawartych w Księdze

${ }^{30}$ Por. K. K ol a ńczyk, Studia..., s. 244-246, Z. R y mas zewski, Prawo bliższości..., s. 185.

${ }^{31}$ N. Michalewicz, O prawie..., s. 103, takż: J. Matuszewski, Aqua..., s. 194; Z. R y m a s zewski, Prawo bliższości..., s. 185 .

${ }^{32}$ Z. Rymaszewski podzielił dostępne źódła na dwa okresy, obejmujące mniej więcej odpowiednio XIII oraz XIV i XV w. Kryterium podziału uzależnione jest od najczéściej występujących stron w sporze na kanwie retraktu, a także najczęściej zaczepianych tytułów alienacyjnych. W XIII w. jedną ze stron w przeważającej liczbie poświadczonych alienacji była instytucja kościelna, dla której dochody $\mathrm{z}$ nieruchomości stanowily drugą, po dziesięcinach, podstawę egzystencji i potęgi; por. K. T y m i e n i e cki, $Z$ dziejów rozwoju..., s. 26 . W tymże wieku przeważającym sposobem alienacji nieruchomości byly darowizny na rzecz instytucji kościelnych. Odsetek zaczepienia darowizn w XIII w. w odniesieniu do wszystkich zaczepianych alienacji $\mathrm{z}$ tytułu prawa bliższości wynosił około 50\%: w materiale z Codex diplomaticus Poloniae (wyd. L. Rzyszczewski, A. Muczkowski, A. Z. Helcel, J. Bartoszewicz, t. I-IV: 1847-1858) -45\%; Kodeks dyplomatyczny Malopolski, (t. I-IV, wyd. F. Piekosiński, Monumenta medii aevi historica, t. III-V: XVII, Kraków 1876-1903), - 59\%; Kodeks dyplomatyczny Wielkopolski (t. I-IV, wyd. I. Zakrzewski, Poznań 1877-1881; t. V, wyd. F. Piekosiński, Poznań 1908) - 56\%. Odnośnie do XIV w. dane wynoszą odpowiednio: 14\%, 5,5\%, 30\%, a w wieku XV - 12,5\%,7\%, 25\%; za: Z. R y maszewski, Prawo bliższości.., s. 96, przyp. 32. Jednakże wspomniane dystynkcje chronologiczne nie są do końca zadowalające. Granica zasadzona na kryterium podmiotowym powinna być przesunięta na lata czterdzieste XIV w. Dowodzą tego choćby dane statystyczne uzyskane w trakcie analizy małopolskich dokumentów dotyczących stosunków prywatnoprawnych. I tak jeszcze w latach 1306-1333 4/5 odbiorców dokumentów dotyczących obrotu ziemią to instytucje kościelne; por. K. Sk u pi ń sk i, Malopolskie dokumenty w sprawach prywatnoprawnych w latach 1306-1368, 
sqdowej brzesko-kujawskiej ${ }^{33}$ zauważył siedem przypadków korzystania z prawa

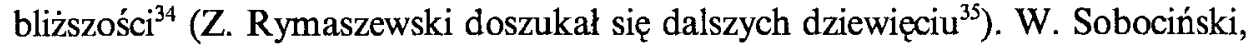
nawiązując do ustaleń $\mathrm{K}$. Kolańczyka, długotrwałość istnienia prawa retraktu motywował jego slabością ${ }^{36}$, do czego nawiązal także $\mathrm{Z}$. Rymaszewski ${ }^{37}$. Ten ostatni jako główny powód utraty znaczenia prawa bliższości uznał zmianę sposobów alienacji nieruchomości w XIV w. Jego zdaniem, konieczność zwrotu ekwiwalentu nieruchomości (retrakt-skup) skutecznie blokowała uprawnionym podmiotom realizację przysługujących im roszczeń, tym bardziej że dochodzily do tego koszty procesu sądowego ${ }^{38}$.

Zgodnie $\mathrm{z}$ wyżej przedstawionym stanowiskiem, upadek znaczenia instytucji wiązałby się z naturalnym procesem desuetudo. Ale czy odpłatność windykacji retraktowych wystarczała, by odebrać instytucji jej pierwotną moc? Gdyby tak było, nie byłyby potrzebne normatywne regulacje omawianej instytucji, których nie brakuje w zwodach praw z XIV i XV stulecia. Ponadto zainteresowani nie próbowaliby stosować różnego typu czynności prawnych i faktycznych, służących do osłabienia prawa retraktu, jakim jest choćby ewikcja $^{39}$. Nawet dokumenty XVI-wiecznej praktyki wskazują na realne zagrożenie ze strony prawa retraktu. Po cóż w 1521 r. pozbywcy malopolskiej

Roczniki historyczne 2000, t. LXVI, s. 58. Dopiero w pot. XIV w. stosunek ten drastycznie się zmienił $-59 \%$ alienacji zostało dokonanych między świeckimi kontrahentami. Por. ibidem, s. 65 .

${ }^{33}$ Ksiegi sqdowe brzesko-kujawskie, 1418-1424, wyd. J. K. K o ch a n ow ski, [w:] Teki Pawińskiego, t. VII, Warszawa 1907 [dalej: BrzKuj.].

${ }^{34}$ B. Lesiński, Ze studiów, s. 106, przyp. 64.

${ }^{35}$ Por. Z. R ymaszewski, Prawo bliższości..., s. 151, przyp. 197.

${ }^{36}$ W. S obociński, [recenzja...], s. 335.

${ }^{37}$ Z. R y m as ze wski, Prawo bliższości..., s. 187.

${ }^{38}$ Por. ibidem, s. 185 . Z drugiej strony, w związku z nasileniem obrotu nieruchomościami, a także rozwojem trzecizny, rozszerzył się zakres przedmiotowy prawa retraktu również na nieruchomości nabyte. Trzecizna pozwalała swobodnie dysponować $1 / 3$ posiadanych nieruchomości - zarówno nabytymi, jak i dziedzicznymi. Przekroczenie tego zakresu, niezależnie czy w stosunku do nieruchomości dziedzicznych czy nabytych, dawało krewnym moc wykorzystania prawa bliższości. Podobnie zwiększenie ilości ziem nabytych $w$ stosunku do dziedzicznych w posiadaniu podmiotu prawa bliższości skłoniło potencjalnych retrahentów do usiłowań rozciągnięcia ius propinquitat is także na nią. Por. ibidem, s. 87.

${ }^{39}$ Ewikcja gwarantowała spokojne posiadanie nieruchomości nabywcy; w zamian za niego odpowiadał z tytułu retraktu zbywca, por. R. T a u ben schlag, Odpowiedzialność za wady prawne przy pozbyciu wlasności w średniowiecznem prawie polskiem, Sprawozdania Polskiej Akademii Umiejętności 1930, t. XXXV, s. 10. Z. R y m a z e wsk i wyraził wątpliwość co do przekonania, jakoby każde występowanie ewikcji w źródłach było potwierdzeniem zabezpieczenia przed prawem bliższości (Prawo bliższości..., s. 22-23). Inaczej np. S. R u s s o cki, Formy wladania..., s. 96. J. S. M atu s zewski wskazuje, że zwiększanie sumy zastawnej prowadzące do sprzedaży także było instrumentem antyretraktowym; tenże, Zastaw nieruchomości w polskim prawie ziemskim do końca XV stulecia, Łódź 1979, s. 39. 
nieruchomości mieliby ukrywać sprzedaż pod tytułem darowizny (darowizna od $1511 \mathrm{r}$. de iure nie podlegala prawu retraktu), gdyby retrakt nie godził w stabilność obrotu prawnego? $?^{40}$

Kwestia normatywnych ograniczeń prawa retraktu już wielokrotnie pojawiała się w literaturze przedmiotu; zajmowane stanowiska stanowią szeroki wachlarz, począwszy od konstatacji istnienia takich ograniczeń, przez wskazanie ich roli, a kończąc na przedstawieniu ich jako najistotniejszych środków ograniczenia prawa retraktu ${ }^{41}$. Opierając się na analizie wspomnianych ograniczeń, warto zastanowić się nad tezą, wedle której pierwotnie prawo retraktu miało siłę zakłócającą stabilność alienacji nieruchomości i $w$ związku $z$ nią powstawały kolejne ograniczenia instytucji, aż do momentu, gdy de facto przestała odgrywać istotne znaczenie w obrocie prawnym. Teza ta oczywiście nie przeczy słusznemu stanowisku Z. Rymaszewskiego, który podkreśla, że zmiana tytułów prawnych stosowania retraktu w naturalny sposób ograniczyła częstotliwość stosowania omawianej instytucji. Lecz gdyby nie było terminów ograniczających wnoszenie pozwu, faktyczne ograniczenie $w$ postaci zwrotu ekwiwalentu nieruchomości nie miałoby tak dużego znaczenia. Wszak rodzina mogła w dłuższym okresie zebrać potrzebną do wykupu kwotę.

O tym, że prawo retraktu stanowiło realne zagrożenie jeszcze w XV w., mimo iż wówczas alienacje odpłatne zdecydowanie górowały nad darowiznami i obowiązywał już szereg jego ograniczeń, informują zreinterpretowane wyniki badań statystycznych przeprowadzonych przez S. Russockiego i Z. Rymaszewskiego. Wyliczenia przedstawiają się następująco. Najniższy procent (jedynie $2,7 \%$ ) protestów w stosunku do wykonanych alienacji stwierdzono na terenach

${ }^{40}$ Decreta in iudiciis regalibus tempore Sigismundi I regis Poloniae a. 1507-1531, Cracoviae celebratis lata..., wyd. M. B obrzy ń ski, [w:] Starodawne Prawa polskiego Pomniki, t. VI, Kraków 1881, nr 213 z 1521 r.

${ }^{41} \mathrm{Na}$ temat znaczenia ograniczeń normatywnych wielokrotnie pojawiały się glosy w literaturze. Wyraźnie podkreśla znaczenie terminów przedawnień B. Lesiński, Ze studiów..., s. 104. J. M a tu szewski (Aqua..., s. 189, przyp. 32), wskazuje na wage nie tyle konkretnej treści ograniczeń, ale na sam fakt ich wprowadzenia. Podobnie J. B a rdach, Historia paŕstwa i prawa polskiego, t. 1, Warszawa 1964, s. 498. Z. R y m a s ze w s ki docenia rolę normatywnych ograniczeń prawa retraktu, jednakże - jak już wspomniano - badacz ten, za W. Sobocińskim, ograniczenia te stawia $w$ hierarchii skuteczności na dalszych pozycjach w porównaniu z samoograniczeniem instytucji opierającym się na konieczności zwrotu ceny alienacji. Por. Z. R y m a szew sk i, Prawo bliższości..., s. 146, 153, 185-187, W. S o b o c iń s k i, [recenzja...], s. 335. S. R u s s o cki, omawiając problem stabilności obrotu nieruchomościami na Mazowszu, wymienił terminy przedawnienia, w tym także odnoszące się do prawa retraktu (Formy wladania..., s. 286-288). 
wschodnich prowincji małopolskiej"2 (na 2405 alienacji jedynie 67 zostało zaczepionych); wynik ten może jednak budzić pewne wątpliwości ${ }^{43} . \mathrm{Z}$ terenu Mazowsza na 667 alienacji sprzeciw zgłoszono w stosunku do 30, co daje $4,5 \%$ zaczepień alienacji ${ }^{44}$. $\mathrm{Z}$ terenu jurysdykcji sądu ziemskiego krakowskiego w latach 1374-1400 na 562 alienacje stwierdzono 44 protesty, co stanowi $7,8 \%{ }^{45}$. Największy odsetek $(16,6 \%)$ znajduje się w brzesko-kujawskich zapiskach sądowych $z$ lat 1418-1424 (na 90 alienacji zaczepionych zostało $16)^{46}$, lecz dane te należy interpretować $\mathrm{z}$ dużą ostrożnością. Pochodzą one z krótkiego przedziału czasowego, a ponieważ materiału statystycznego jest niewiele, więc każda dodatkowa wzmianka powoduje znaczne zmiany w otrzymanych obliczeniach, co widoczne jest przy porównaniu wyników B. Lesińskiego i Z. Rymaszewskiego (por. wyżej).

Po odrzuceniu najbardziej skrajnych i jednocześnie kontrowersyjnych danych, pozostają dwie wartości: $4,5 \%$ dla Mazowsza i 7,8\% dla obszaru jurysdykcji ziemskiego sądu krakowskiego. Czy rzeczywiście retrakt nie oferował skutecznego sposobu rewindykacji, skoro nie tylko 4 , ale $8 \%$ wszystkich alienacji zostało zaczepionych? Zdecydowana większość przebadanego przez Rymaszewskiego materiału pochodzi z drugiego okresu proponowanego przez niego podziału, w którym wzrasta obrót nieruchomościami. Jeszcze w XIII i pierwszych dziesięcioleciach XIV w. prawo miało służyć zabezpieczaniu wlasności, akcent położony był na bierny stosunek do nieruchomości; prawo bliższości odgrywało więc pozytywną rolę, bowiem w XIII w. nastąpił żywiolowy rozwój tej instytucji. Później istotną sprawą staje się swobodny obrót prawny, akcent $\mathrm{z}$ pasywności przesuwa się na aktywność $\mathrm{w}$ sferze obrotu nieruchomościami, retrakt ma tutaj charakter negatywny ${ }^{47}$. Zgodnie

${ }^{42}$ Na podstawie Akt grodzkich i ziemskich z czasów Rzeczypospolitej Polskiej z Archiwum tak zwanego bernardyńskiego we Lwowie wskutek fundacji śp. Aleksandra hr. Stadnickiego wydane staraniem Galicyjskiego Wydzialu Krajowego, t. I-IX, XI-XIX, Lwów 1868-1906 [dalej: AGZ], Z. R ymaszewski, Prawo bliższości..., s. 151.

${ }^{43}$ Loc. cit.

${ }^{44} \mathrm{Na}$ podstawie Metryki ks. mazowieckiego z $X V-X V I$ w., wyd. t. I-II, [w:] Pomniki prawa wydane przez Warszawskie Archiwum Glówne, t. V-VII, Warszawa 1918-1930 [dalej: MKM I i II], S. Russocki, Formy wladania..., s. 103. Przebadany materiał obejmuje teren Księstwa Mazowieckiego i pochodzi z lat 1417-1433.

${ }^{45} \mathrm{Na}$ podstawie Najdawniejszych ksiag sqdowych krakowskich, wyd. B. Ula now k i, [w:] Starodawne Prawa Polskiego Pomniki, t. VIII, cz. 1-2, Kraków 1884-1886, Z. R y m a s z w s k i, Prawo bliższości..., s. 151.

${ }^{46} \mathrm{Na}$ podstawie Brz. Kuj, Z. R y m as zewski, Prawo bliższości..., s. 151.

${ }^{47}$ Oczywiście, nie jest możliwe ostre zarysowanie granicy między proponowanymi okresami. Ponadto w różnych częściach Królestwa proces ograniczania prawa retraktu rozpoczął się $\mathrm{w}$ innym momencie, por. niżej. Natomiast zdaniem J. Wr on is zewskie go, w drugiej połowie XIV i w wieku XV retrakt spehniał swą rolę $w$ przypadku alienacji ziemi poza ród; te nże, Szlachta ziemi..., s. 39-42. Na odsetek zaczepianych transakcji z pewnością miał wpływ fakt, czy niepokojonym nabywcą był ktoś spoza rodu. 
z tym można stwierdzić, że o ile kilkuprocentowa skuteczność prawa bliższości w odniesieniu tylko do wieku XIII świadczyłaby o jego słabości, to w wiekach XIV i XV, w okresie, gdy retrakt nie pełni pozytywnej, ale juź negatywną rolę, prawie $8 \%$ rewokacji w obrębie jurysdykcji sądu ziemskiego krakowskiego musiało poważnie zagrażać pewności obrotu gospodarczego. Ponadto między zainteresowanymi stronami mogło wielokrotnie dochodzić do kompromisu, którego treść nie została odnotowana w księgach sądowych ${ }^{48}$. Na tej podstawie warto zapytać, czy w rzeczywistości nie było tak, że spadek odsetka zaczepionych alienacji $\mathrm{w}$ czasie wiązal się $\mathrm{z}$ zastosowywaniem normatywnych ograniczeń skuteczności prawa retraktu? Gdyby prawo retraktu nie miało większego znaczenia praktycznego, wówczas w kodyfikacjach zwyczajowego prawa ziemskiego nie następowałoby modyfikowanie pierwotnych norm (por. niżej). Logicznie więc $\mathrm{z}$ tego wynika, że im później, tym mniej powinno być zaczepionych alienacji. Rozumowanie to jest bliskie stanowisku B. Lesińskiego ${ }^{49}$.

Wspomniane ograniczenia sily prawa retraktu dotyczyły kilku aspektów: ustalenia czasu przedawnienia roszczeń krewnych $w$ stosunku do zbytej nieruchomości, ustalenia czasu przeznaczonego na wykup - od momentu uzyskania wyroku sądowego, kształtowania procedury informowania krewnych o chęci alienowania nieruchomości, wreszcie stopniowego ograniczania kręgu uprawnionych i tytułów alienacyjnych podlegających prawu bliższości ${ }^{50}$. Niektóre regulacje były autorstwa legislatorów (np. zmiany czasu przedawnienia w Statutach Kazimierza Wielkiego), lecz częściej zapisem prawa zwyczajowego. Niżej zostanie przedstawionych kilka przykładów normatywnych ograniczeń prawa retraktu.

${ }^{48}$ Przykładowo dobrowolne ustąpienie z dóbr przed bliskimi - Brz.Kuj., nr 3104 z 1423 r., AGZ XVI, nr 76 z 1464 r.; konsensus uzyskany w czasie procesu - Pommerellisches Urkundenbuch, wyd. M. Perlbach, t. I-II, Gdańsk 1881-1882, nr 573 z 1299 r. Poza tym instytucje kościelne niechętnie odnotowywały swoje porażki, co zmniejsza liczbę dokumentów informujących o retrakcie.

${ }^{49}$ B. Lesiński, Ze studiów..., s. 104.

${ }^{50}$ Analiza źródeł wskazuje, że częściej regulacje dotyczyły elementów mających znaczenie w pierwszej kolejności procesowe (terminy) niż dotyczących istoty retraktu (zakres podmiotowy i tytuły podlegające zaczepieniu). Może to wynikać $z$ charakterystycznego $w$ średniowieczu przekonania, wedle którego stare prawo jest lepsze; regulacje formalne mogly być lepiej przyjęte przez ogół adresatów norm - zarówno w odniesieniu do zwyczajowego formowania się prawa, jak i przede wszystkim wobec świadomej legislacji. Tym też, obok jednostronnego dążenia możnych (aby łatwo było zdobywać nieruchomości i nadal trudno je tracić, por. Z. R y maszewski, Prawo bliższości..., s. 187), można thumaczyć fakt, że prawo retraktu nie zostało zniesione jednorazowym postanowieniem. 
3.1. Większość badaczy przyjmuje, że pierwotnie prawo retraktu nie posiadało ograniczeń $w$ zakresie terminów jego stosowania ${ }^{51}$. W stosunku do zbytej nieruchomości przechodziło ono dziedzicznie, co ilustrują poniższe przykłady. W roku 1288 pretensje do majątku darowanego biskupstwu krakowskiemu przez scholastyka Wysza wytoczyła jako jedyna z rodu scholastyka jego bratanica. Spór zakończyl się ugodą i ustępstwami $\mathrm{z}$ obu stron ${ }^{52}$. Mimo iż przypadek ten dotyczył $\mathrm{w}$ pewnej mierze praw spadkowych, siostrzenica powołała się słusznie na prawo retraktu ${ }^{53}$. Inny wypadek dotyczył trwającego kilka pokoleń sporu Pałuków z klasztorem w Łeknie ${ }^{54}$.

Pierwsza znana informacja o terminie przedawnienia pochodzi $\mathrm{z}$ dokumentu praktyki z terenu Mazowsza z $1285 \mathrm{r}$.. Na tej podstawie R. Hube domyśla się wydania ustawy wprowadzającej trzyletni termin przedawnienia ${ }^{55}$. Natomiast $w$ Małopolsce pierwsze normatywne regulacje monarsze tego problemu pochodzą z 1338 r. Kazimierz Wielki przyznał przedawnienie po upływie roku $w$ odniesieniu do określonych wypadków ${ }^{56}$. Termin ten uległ zmianie $w$ postaci art. XV Statutu malopolskiego, w którym przyjęto jako okres przedawnienia termin trzech lat $\mathrm{i}$ trzech miesięcy ${ }^{57}$.

Stopniowe skracanie terminu przedawnienia roszczeń jest widoczne na podstawie prawa wielkopolskiego. Najstarsze teksty Statutu wielkopolskiego zawiera art. IX, w którym termin ten wynosił 8 lat $^{58}$ (S. Roman przychylił się do koncepcji, wedle której powstanie terminu przedawnienia było starsze - 1347 r. - od samej kodyfikacji, po 1356 r. ${ }^{59}$ ). Ekstrawaganty wielkopolskie wprowadziły w art. XLVIII (De cetero statuimus...) termin trzech lat i trzech

${ }^{51}$ Ibidem, s. 145 , przyp. 156; K. K ol a ń czy k, Studia.., s. 261, przyp. 480.

${ }_{52}$ Por. B. Le siński, Ze studiów..., s. 95.

${ }^{53} \mathrm{~W}$ myśl separacji prawa retraktu i prawa spadkowego obiekcje może wywołać posłużenie się zaprezentowanym przez B. Lesińskiego przykładem z 1328 r., w którym siostra zbywców nieruchomości dla klasztoru w Byszewie pozwała opata z konwentem o 1/4 zbytej dziedziny jako przysługującą jej czwarciznę po ojcu. (Ze studiów..., s. 96).

${ }^{54}$ K. Kolańczyk, Studia..., s. 261.

${ }^{55} \mathrm{R}$. Hube, Prawo polskie $w$ wieku trzynastym..., s. 111.

${ }^{56}$ Król potwierdził darowiznę części Brzezia dokonaną przez Stanisławę i Wisenegę na rzecz ich siostrzenicy Felicyi, zastrzegając proskrypcje jednego roku dla wykupu. Por. S. K ęt r zyński, O elementach chronologicznych dokumentów Kazimierza Wielkiego, Kraków 1913, s. 98.

${ }^{57}$ Artykuł LXXV w rekonstrukcji O. B a $1 \mathrm{z}$ er a, Statut malopolski Kazimierza Wielkiego, wyd. O. Balzer, Poznań 1947, s. 446.

${ }^{58}$ IX (art. $116 w$ rekkopisie królewieckim $z$ ok. 1430 r.) Preterea statuimus et edicto perpetuo servari mandamus, quod quicunque venditam possesionem infra octo annos, volens in ea aliquod ius vendicare...; S. R o m a n, Geneza Statutów Kazimierza Wielkiego. Studium źródloznawcze, Kraków 1961, s. 144.

59 Ibidem, s. 152. 
miesięcy ${ }^{60}$, znany z kodyfikacji wiślickiej. De facto, to wlaśnie ten przepis stał się ogólnie obowiązującym na gruncie Dygestów malopolsko-wielkopolskich ${ }^{61}$. W thumaczeniu Świętosława $\mathrm{z}$ Wojcieszyna przepis brzmi następująco:

CXXI. O dawnoszcz wykupyenya dzyedziny. De cetero infra. - Przeczywko kupyaczemu dzedzyna blyszczy do trzech lyaatch y trzech myeszanczi czynycz maya, bo potheem dawnoscz gym drogq zastanpy ${ }^{62}$.

B. Lesiński, na podstawie zapisek wielkopolskich, udowodnił powstanie tam przed 1409 r. uchwały, która wprowadzała zaledwie sześciotygodniowy termin przedawnienia roszczeń retraktowych ${ }^{63}$. Pierwsza zapiska, w której znajduje się ten termin, pochodzi $\mathrm{z}$ roku $1394^{64}$.

$\mathrm{Na}$ terenie Mazowsza płockiego okres roku i sześciu tygodni przedawnienia roszczenia retaktowego gwarantował statut sochaczewski Siemowita IV z $1387 \mathrm{r}^{65}$ Podobne regulacje objąl przywilej Władysława I dla szlachty ziem płockiej, wiskiej, płońskiej i zakroczymskiej z połowy XV w. ${ }^{66}$ Taki też termin proponowano w Zwodzie Prażmowskiego ${ }^{67}$. W pozostałej części Mazowsza obowiązywal trzyletni okres przedawnienia zawarty w statucie księcia Siemowita III z 1377 r. $^{68}$, następnie potwierdzony w swym księstwie

${ }^{60}$ XLVIII. De cetero statuimus, quod cum aliquis emens hereditatem et ipsam tenens tribus annis et tribus mensibus pacifice et quiete, et si ipsam aliquis consanguineus vel affinis post predictos annos impedierit. Volens ipsum exemere per proximitatem de eadem hereditate viceversa, statuimus, quod, ex quo idem proximior tacuit annis tribus et tribus mensibus prenotatis, amodo non sit ei lictum predictam hereditatem rehabere; Statuty wielkopolskie, wyd. L. Lysiak, Poznań 1982, s. 62.

${ }^{61}$ R. Hu be, Prawo polskie w $14 \ldots$, s. 87 i n.

${ }^{62}$ Statuty Kazimierza Wielkiego w tlumaczeniu Świętoslawa z Wojcieszyna. Kodeks Świetoslawów, wyd. F. Piekosiński, [w:] Archiwum Komisji Prawniczej Akademii Umiejętności, t. III, Kraków 1895 , s. 248.

${ }^{63}$ Por. B. Lesiński, Ze studiów..., s. 105.

${ }^{64}$ Die ältesten grosspolnischen Grodbücher, wyd. J. Lekszycki, t. I, Leipzig 1887, nr 1734 i 1764.

${ }^{65}$ II. Item, praedictus dominus Dux cum prefatis suis dominis statuit, quod quando aliquis militum, sive quorumcumque hominum sua aliqua bona, videlicet hereditatem aut molendinum, vel aliquid aliud, pro pecuniis sive aliis rebus cuicumque homini vendiderit, illa venditio infra spacium unius anni et sex septimanarum stare debet: et si per aliquem illius venditoris amicum in dicto termino, videlicet unius anni et sex septimanarum dicta bona vendita non fuerint redempta in pecuniis eisdem, extunc dicta vendicio in perpetuum stare et permanere debebit, ita, quod nullus de ipsis bonis venditis amovere se debet; Iura Masoviae Terrestria, t. 1, wyd. J. Sawicki, nr 34, s. 50.

${ }^{66}$ S. R u s sock i, Formy wladania..., s. 101.

${ }^{67}$ Ibidem, s. 287.

68 16. [...] Et si quispiam pro suis campis vel aliis usibus ad spacium trium annorum taceret, tacere debet imperpetuum; Iura Masoviae, $\mathrm{nr} 22$, s. 33. 
przez księcia Janusza I w $1390 \mathrm{r} .{ }^{69}$ Termin ten potwierdzony jest praktyką wieku $\mathrm{XV}^{70} \mathrm{i}$ ostatecznie przyjęto go w szesnastowiecznym Zwodzie Goryńskiego $^{71}$.

Natomiast regulacje prawa bliższości w ziemi łęczyckiej zawarto w kodyfikacji Constitutiones et iura terrae Lanciciensis (1418-1419). Według badań Z. Rymaszewskiego, terminem zawitym zglaszania roszczeń był okres roku i sześciu tygodni zapisany ogólnie jako termin prekluzyjny w artykule II $^{72}$. Taki sam termin występował na Kujawach u schyłku wieku XIV (w XV w. ulegnie skróceniu do 6 tygodni); świadczy o tym np. zapiska z księgi ziemskiej przedeckiej z 1399 r.:

Dnus Bogusiaus de S. debet et tenetur soluere per unum annum et sex septimanas C. sexag. pro hereditate media dicta Schwensko dno Petrassio de K. Si vero idem B. non crediderit... ${ }^{73}$

Warto jeszcze podkreślić, iż podane wyżej terminy nie dotyczyły pewnej kategorii osób. W Zwodzie Goryńskiego w odniesieniu do dóbr wiennych sprzedanych przez męża przedawnienie rozpoczynało swój bieg dopiero po jego śmierci ${ }^{74}$. W Statutach Kazimierza Wielkiego wdowa mogła dochodzić swych praw do dóbr wiennych w ciągu sześciu lat ${ }^{75}$. Ponadto $w$ świetle Statutów termin przedawnienia rozpoczynal swój bieg od momentu uzyskania

${ }^{69}$ 8. Hereditatis vendicio redimatur per propinquos. Item, si aliqui terrigene pro suis bonis sive hereditatibus forum perpetuum in presencia ducis contraxerint et munimenta super eo ducis iperent in testimonium sue emcionis, et si infra trennium a tempore vendicionis propinquiores amici euisdem vendentis huiusmodi emcionem pro eisdem bonis venditis in iudicio non attentaverint, aut huiusmodi bona non redimerent, extunc elapso predicto trienno imperpetuum tacere debebunt; Iura Masoviae, nr 39, s. 59.

${ }^{70}$ MKM II, $\mathrm{nr} 15,23,48,95,97,176,178,210,254,273,274,366$; Metryka Ksiestwa Mazowieckiego - Metryka Koronna, t. 5, f. 102, za: S. R u s s o c k i, Formy wladania..., s. 102.

${ }^{71}$ De praescriptione propinquitatis acquisitae. Quando aliquis emit et acquirit propinquitatem redimendi aut revocandi aliquam haereditatem a quacunque persona, non currit ei praescriptio $a b$ emptione, sed $a b$ apprehensione possessionis, et effectuali intromissione in eandem haereditatem, a qua possidens pacifice trienno iustam praescriptionem acquirit et perpetuam firmitatem; Statuta Ducatus Masoviae, wyd. J. Sawicki, Iura Masoviae Terrestria, t. III, Warszawa 1974, s. 181 .

${ }^{72}$ II. [...] prescriptio pro hereditatibus empties et venditis stat annus et VI septimane; Constitutiones et iura terre Lanciciensis ad fidem Codicum Ptrb. III et Sier. IV, wyd. B. Ulanowski, [w:] Archiwum Komisji Prawniczej, t. IV, Kraków 1911, s. 435 i n. [dalej: Constitutiones].

${ }^{73}$ R. Hu be, Sady..., s. 163.

${ }^{74}$ S. R u s s o ck i, Formy wladania..., s. 287.

${ }^{75}$ LXXV. Si vero sit mulier maritata, et aliquam hereditatem, quam dicit et credit racione dotis vel quomodolibet ad se pertinere, si infra decem annos non curaverit vel neglexerit pro eadem hereditate questionem internate, ita quod infra tempus idem pacis et concordie paciatur possessorem quiete possidere, extunc decrevimus, quod eadem mulier ab omni iure hereditatis predicte se cognoscat cecidisse. Si autem fuerit vidua, et eodem modo dicat et asserat aliquam hereditatem, 
lat sprawnych ${ }^{76}$. Natomiast przepisy Zwodu Goryńskiego (wobec nieobecnych) i Statutów Kazimierza Wielkiego (wobec jeńców wojennych) wstrzymywały bieg przedawnienia aż do momentu powrotu ${ }^{77}$.

3.2. Terminy realizacji zasądzonego przez sąd roszczenia retraktowego przedstawiały się następująco ${ }^{78}$. W Małopolsce termin ten wytworzyła praktyka sądowa; nie zostal on zawarty w Statucie wiślickim. W 1354 r. Helka pozwała kanonika krakowskiego Piotra o połowę wsi kupionej przez tegoż od jej brata, twierdząc, że już w roku 1348 przyznano jej prawo wykupu. Powódkę odsądzono, ponieważ od okresu przyznania retraktu minęło 6 lat, a nie zwyczajowo uznany w Małopolsce rok i 6 tygodni $^{79}$. W ziemi lęczyckiej w wieku XV termin był stały i upływal wraz $\mathrm{z}$ Nowym Rokiem $^{80}$, na Mazowszu ustalil się termin osiemnastu tygodni ${ }^{81}$, najkrótsze terminy w XV w. obowiązywały na Kujawach i w Wielkopolsce - sześć tygodni ${ }^{82}$. Ilustruje to zapiska sądowa kaliska z 1411 r.:

$M$. de S. propinquitate acquisivit hereditatem ibidem in S. erga L., pro qua sibi L, tenetur dare XIII mar., quas tenetur dare in VI septimanis, quas si non dederit, tunc idem $M$. sciat, se predictam hereditatem amisisse ${ }^{83}$.

Pozostaje jeszcze jeden termin pochodzący z Constitutiones et iura terre Lanciciensis, a dotyczący wydania konfirmacji alienacji przez sąd ziemski. Z. Rymaszewski dokonał krytyki niniejszego aktu, odczytując na nowo treść artykułu XXII; poprzednio odczytywano zawarty w nim zapis o sześciu tygodniach jako termin przedawnienia zgłaszania roszczenia. Wedhug badacza, sześciotygodniowy termin zgłaszania roszczenia gwarantował cen̨̧ wykupu równą cenie sprzedaży, później ona wzrastała. Ostatecznie Statut piotrkowski z 1493 r. ustanowił dla ziemi łęczyckiej zbliżony do terminu znanego ze Statutów Kazimierza Wielkiego okres 3 lat i 6 tygodni ${ }^{84}$. W legislacji tej widać próbę ujednolicenia prawa ziemskiego w skali kraju.

quam aliquis possidet, racione dotis vel quolibet alio iure ad se pertinere, et infra sex annos tempore pacis et concordie sustinuerit et passa fuerit eundem possessorem ipsam hereditatem quiete possidere, decrevimus, quod extunc ipsi possessori racione prescriptionis in eadem heredeitate plenum ius sit aquisitum, et mulier senciat se ab omni iure hereditatis cecidisse; Statut malopolski Kazimierza Wielkiego, wyd. O. Balzer, Poznań 1947, s. 446.

${ }^{76}$ Por. przyp. 92.

${ }^{77}$ S. Russ ock i, Formy wladania..., s. 287.

${ }^{78}$ Pelny katalog tych terminów podaje Z. R y m a s zew sk i, Prawo bliższości..., s. 149, przyp. 184.

${ }^{79}$ B. Lesiński, Ze studiów..., s. 96.

${ }^{80}$ Z. R y maszewski, Prawo bliższości..., s. 150.

${ }^{81}$ S. R ussocki, Formy wladania..., s. 101.

${ }^{82}$ Por. B. Lesiński, Ze studiów..., s. 107.

${ }^{83}$ R. Hube, Sqdy..., s. 163.

${ }^{84}$ S. Russ ock i, Formy wladania..., s. 287. 
3.3. Także zmiany $w$ zakresie postępowania alienacyjnego ograniczaly prawo retraktu. Do zmian tych należały omówione już wcześniej terminy przedawnień, a także formularz postępowania stosowany $\mathrm{w}$ Wielkopolsce i na Kujawach. B. Lesiński na podstawie analizy czterech przypadków sugeruje wydanie w Wielkopolsce przed 1409 r. uchwały dotyczącej ogłaszania kupna nieruchomości ziemskich ${ }^{85}$. Treść dokumentu ogłaszano (czynił to woźny lub nabywca w obecności woźnego sądowego) trzykrotnie na kolejnych roczkach sądowych, cala operacja trwała więc 6 tygodni. Jeśli w tym czasie krewni nie zgłosili chęci zrealizowania uprawnień retraktowych (wszak nieruchomość została już sprzedana, nabywca ogłaszal dokument alienacyjny, a nie jego zapowiedź), nowonabywca otrzymywal dokument potwierdzający alienację od sądu, który miał wartość dowodową ad probationem ${ }^{86}$.

3.4. W zakresie tytułów prawnych podlegających prawu retraktu Z. Rymaszewski wymienia kolejno: darowiznę, zamianę, sprzedaż, zastaw i dzierżawę ${ }^{87}$. Istnieją źródła normatywne, które potwierdzają usunięcie $\mathrm{z}$ zakresu tytułów podlegających prawu retraktu darowiznę i zamianę. S. Russocki dokonał krytyki Statutu warszawskiego z 1410 r., w którym wykluczono zamianę $\mathrm{z}$ pola działania retraktu; przepis ten okazal się interpolacją ${ }^{88}$. Nie zmienia to faktu, że zamiana zastała wykluczona w Zwodzie Goryńskiego z 1540 r., a także (według S. Russockiego dopiero wówczas zakaz ten w rzeczywistości zaczyna funkcjonować) w Eksceptach mazowieckich z 1576 r. $^{89}$ Ponadto konstytucją sejmową z 1511 r. zniesiono w Koronie retrakt darowizny ${ }^{90}$. Natomiast podmiotowy zakres prawa retraktu ulegał mniejszym ograniczeniom. Wbrew tezie $Z$. Rymaszewskiego, wprowadzenie terminów przedawnień nie ograniczylo zbyt mocno moźliwości stosowania retraktu przez wnuków ${ }^{91}$, wszak już w Statutach Kazimierza Wielkiego umieszczono przepis wstrzymujący bieg przedawnienia na czas małoletniości (do czasu osiągnięcia dwunastego roku życia) ${ }^{92}$. W artykule 41 Constitutiones et iura terrae Lanciciensis znajduje się zapiska ograniczająca retrakt brata stryjecznego

${ }^{85}$ Por. B. Lesiński, Ze studiów..., s. 105.

${ }^{86}$ Ibidem, s. 106.

${ }^{87}$ Z. R y mas zew ski, Prawo bliższości..., s. 90-106.

${ }^{88}$ S. R u s s ocki, Formy wladania..., s. 100.

${ }^{89}$ Por. niżej.

${ }^{90}$ Por. J. Matuszewski, Aqua..., s. 191, przyp. 34.

91 Z. R y mas zewsk i, Prawo bliższości..., s. 49.

92 Similiter infantibus ad duodecim annos educatis, si tempore infancie per quemvispiam iniuria fuerit illata, aut patri ipsorum tunc mortuo possunt illatam violenciam agitare, pro qua agere non valebant propter defectum etatis, contra ipsos inpedientes seu iniuriantes. Excepcio prescriptionis opponi non poterit, nisi tunc legitima etate in eis conpleta infra tempus debitum agere negligerent pro iniuriis olim eis illatis; tunc obstabit eis exceptio prescripcionis propter neglegenciam allegatam; artykuł LXXIV w rekonstrukcji O. B alzera, Statut..., s. 442. 
na rzecz siostry ${ }^{93}$; miała ona na celu harmonizacje działania retraktu i jednocześnie przelamywała zasadę paterna-paternis ${ }^{94}$. Natomiast na Mazowszu obowiązywał przepis, w którym zakazano synom wzruszać alienacje ojcowskie, jak długo on żyl. Norma ta nie była stosowana w sytuacji, gdy ojciec powtórnie się ożenil ${ }^{95}$.

3.5. Ustalenie czasu ostatecznego zaniku prawa retraktu jest kwestią sporną. Konkretne stanowiska determinowane są odpowiedzią na pytanie, czy obowiązywanie norm mierzy się występowaniem w praktyce obrotu prawnego, czy też według zapisów w tekstach normatywnych. I tak wedle pierwszego stanowiska uznaje się przelom stuleci XV i XVI (poglądowi temu przeczą świadectwa stosowania tej instytucji jeszcze w XVI wieku), a ze stanowiska formalnoprawnego wysuwa sie rok 1777 (rezolucja Rady Nie-

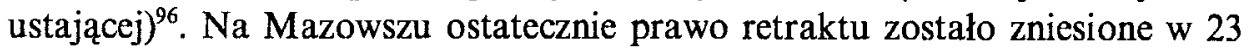
artykule Eksceptów mazowieckich z 1576 r.:

...wiecznie $i$ niezlomnie zachowane wiecznymi czasy, a żadna osoba $w$ linii krewności ich prawem, bliskościq tego frymarku odezwać ani przenagabywać nie może $e^{97}$.

$\mathrm{Na}$ koniec nieodzowne jest naszkicowanie problemu zgodności praktyki prawnej z normami statutowymi; wielokrotnie okazuje się, że w tej materii istniała spora rozbieżność. Już $R$. Hube podkreślal, że nawet Kazimierz Wielki, mający wizję stabilnego obrotu gospodarczego opartego na jednolitym prawie pisanym ${ }^{98}$, powoływał się na zwyczaj zamiast na swoje skody-

${ }_{93}$ Constitutiones, s. 444-445.

94 J. B i e n i k, Rody rycerskie..., s. 195-197.

${ }^{95} \mathrm{~K}$. Du n in, Dawne mazowieckie prawo, s. 156.

${ }_{96}$ B. Le siński, Ze studiów..., s. 104, przyp. 51.

${ }^{97}$ Zwyczaje Województwa Mazowieckiego, z starego statutu, przystawiajqc do prawa koronnego wyiety y zostawione na Seymie walnym toruńskim a. D. 1576, wyd. J. Ohryzko, Volumina Legum, t. I, 1888, nr 939.

${ }^{98}$ Por. K. Skupieński, Malopolskie..., s. 84. Analiza statystyczna dokumentów prywatnoprawnych pozwoliła wspomnianemu badaczowi (ibidem, s. 71), widzieć w ustawodawczej polityce Kazimierza Wielkiego tworzenie warunków pewności obrotu prawnego i wzmacniania praw indywidualnego właściciela. Wyrazem tego był np. spadek liczby dokumentów konfirmacyjnych monarchy pełniących wcześniej, według hipotezy J. A da m u sa, ( $Z$ badań nad dzierżeniem w polskim prawie średniowiecznym, Pamiętnik Historyczno-Prawny 1933, t. XII, z. 5 , s. 85 i n.), rolę kontroli monarszej nad obrotem prawnym. Inaczej Z. W o j c i e ch ow s k i, który widział źródło konfirmacji w staraniach kontrahentów alienacji do uzyskania faktycznego umocnienie stosunku prawnego, por. te nże, Sqdownictwo..., s. 38 n., 45 n. K. Skupieński 
fikowane Statuty ${ }^{99}$, licząc się w ten sposób z przyzwyczajeniami spolecznymi. W. Lysiak odnalazł zaledwie pięć XV-wiecznych źródeł z terenu Małopolski, których wystawcy powołują się na postanowienia Statutu ${ }^{100}$. Problem nieprzestrzegania Statutów Kazimierza Wielkiego próbowano rozwiązać, nakazując w przywilejach czerwińskim, warckim i nieszawskim stosowanie prawa spisanego ${ }^{101}$. Także na Mazowszu nie od razu przestrzegano postanowień statutowych, skoro - jak twierdzi S. Russocki - retrakt wobec zamiany zostal de facto zlikwidowany dopiero Eksceptami z 1576 r.

Znane są dokumenty praktyki małopolskiej, w których znajduje się termin przedawnienia krótszy o trzy miesiące niż w Statutach (zapiska z 1396 r.):

D. vendidit mediam hereditatem $P$. cum omni jure et dominio, nihil pro se reservando, Petrassio [...] et debet ipsum intercedere per tres annos ${ }^{102}$.

Podobnie w Wielkopolsce (zapiska z 1391 r.):

St. de G. Veniens ad judicium optinunt in $P$. de $U$., quod sibi debet [...] partem hereditatis [...] resignare [...] et secundum jus terrestre exbrigare per tres annos pacifice ${ }^{103}$.

Nie oznacza to jednak, że prawo pisane nie ograniczało prawa retraktu w praktyce. Wszak często było nim spisane prawo zwyczajowe, ponadto niektóre regulacje były przyjmowane w obrocie prawnym (np. od początku

zauważył duży skok w liczbie dokumentów (oczywiście dane te nie są pelne ze względu na niezachowanie się wielu dokumentów) w następujących przedziałach czasowych. $Z$ lat 1333-1353 w Małopolsce wydawano około trzy dokumenty prywatnoprawne rocznie, w okresie następnych sześciu lat następuje wyższy niż dwukrotny wzrost, a w ostatnim dziesięcioleciu rządów Kazimierza Wielkiego powstawało około dwanaście dokumentów prywatnoprawnych rocznie. Dla porównania warto jeszcze zaznaczyć, iż w czasach Henryka Brodatego wydawano rocznie średnio około cztery dokumenty prywatnoprawne, a w okresie rządów Władysława Lokietka powstawało około dwa takież dokumenty (R. S k u pie ńs k i, Malopolskie..., s. 63). Ponadto autor potwierdził teze o ograniczaniu roli Kościoła w obrocie ziemią; w ciągu 25 lat od objęcia rządów przez Kazimierza Wielkiego Kościół utracił $25 \%$ udziału w obrocie nieruchomościami. Zachowały siẹ także bezpośrednie wzmianki informujące o niechęci Kazimierza Wielkiego do obdarowywania instytucji kościelnych; monarcha udzielał zgody na nowe nabytki tylko w indywidualnych przypadkach, i to niechętnie. Por. także J. L u ci ński, Majqtki ziemskie panujqcego w Malopolsce do 1385 roku, Poznań 1967, s. 84.

${ }^{99}$ R. H u be, Prawo polskie w $14 \ldots$, s. 224 i n.

${ }^{100}$ L. Lysiak, Statuty Kazimierza Wielkiego $w$ Malopolskiej praktyce sqdowej XV wieku, Studia Historyczne 1976, t. XIX, s. 30-32.

101 Ibidem, s. 28.

${ }^{102}$ Por. R. H u be, Sądy..., s. 161.

${ }^{103}$ Loc. cit. 
$\mathrm{XV}$ w. sześciotygodniowe terminy przedawnień $\mathrm{z}$ terenu Wielkopolski). Akceptacja nowych rozwiązań mających znaczenie przede wszystkim proceduralne (kwestia terminów) przy odrzucaniu nowości dotyczących istoty instytucji (problem zamiany na Mazowszu) jest świadectwem przywiązania ówczesnego społeczeństwa do starego prawa, którego wyrazem były bardziej elementy materialne niż proceduralne.

Prawo bliższości początkowo oddziaływało na prawie wszystkie (z wyjątkiem wiernej ręki i sekwestru) rodzaje alienacji nieruchomości w średniowieczu. Jego istota prowadziła do szeregu uchwytnych w źródłach zatargów, które godziły w stabilność i pewność obrotu gospodarczego. Rozwój tej instytucji w XIII w. podyktowany byl potrzebą $m$.in. windykacji rodowych darowizn ziemskich na rzecz Kościoła. W XIV wieku widoczna jest zmiana liczby alienacji darmnych w stosunku do odpłatnych, szczególnie wskutek zmniejszenia darowizn na rzecz instytucji kościelnych. Z. Rymaszewski widzi $w$ tym główny powód zmniejszenia roli prawa retraktu. Jednakże siła tej instytucji, z przyczyn faktycznych nie wykorzystywana już od drugiej połowy XIV w. tak często, jak w okresie poprzednim, nadal stanowila zagrożenie dla stabilności obrotu prawnego. Tym można thumaczyć szereg normatywnych ograniczeń, czy to $w$ formie intencjonalnego ustawodawstwa królewskiego (lub książęcego), czy w formie prawa zwyczajowego.

Prawo retraktu, sukcesywnie ograniczane na drodze normatywnej (ograniczenia faktyczne, oprócz obstrukcji procesowej, a także ukrywaniem alienacji, np. pod pozorem nadania królewskiego ${ }^{104}$, nie dawały większego efektu), traciło swą silę i doniosłość w średniowiecznym obrocie prawnym. Ograniczenia te były wyrazem postulatów stron zainteresowanych stabilnością obrotu prawnego. Podkreślane przez Z. Rymaszewskiego naturalne ograniczenie skuteczności prawa retraktu przez spadek liczby darowizn było procesem niezależnym od intencjonalnych działań prawotwórczych, wydarzających się w Polsce średniowiecznej.

${ }^{104}$ Przyklad wsi Mogilany: Z. Wojciechowski, Prawo..., s. 54 i n.; M. Sczaniecki, op. cit., s. 28,44 i n. 